\title{
Analysis of Army Recruiter Selling Techniques
}

\author{
Lawrence B. Chonko, Charles S. Madden, \\ John F. Tanner, and Roger Davis \\ Strategic Research Associates
}

\section{Manpower and Personnel Policy Research Group Curtis L. Gilroy, Chief \\ Manpower and Personnel Research Laboratory Zita M. Simutis, Director}

U.S. Army Research Institute for the Behavioral and Social Sciences 5001 Eisenhower Avenue, Alexandria, Virginia 22333-5600

Office, Deputy Chief of Staff for Personnel

Department of the Army

\section{April 1991}

